\title{
Congenital toxoplasmosis: perception of knowledge and primary prevention measures among healthcare professionals and pregnant women treated in public healthcare facilities
}

\author{
Toxoplasmose congênita: percepção do conhecimento e medidas de prevenção primária \\ entre profissionais de saúde e gestantes atendidas em unidades públicas de saúde
}

Fernanda Loureiro de Moura ${ }^{1} \bowtie$, Patricia Riddell Millar ${ }^{2}$, Ana Beatriz Monteiro Fonseca ${ }^{3}$, Maria Regina Reis Amendoeira ${ }^{1}$

${ }^{1}$ Instituto Oswaldo Cruz - Fiocruz, Laboratório de Toxoplasmose e Outras Protozooses. Rio de Janeiro, RJ.

2 Universidade Federal Fluminense (UFF), Instituto Biomédico. Niterói, RJ.

${ }^{3}$ Universidade Federal Fluminense (UFF), Instituto de Matemática e Estatística. Niterói, RJ.

\section{ABSTRACT}

Aims: To evaluate knowledge about toxoplasmosis among pregnant women and healthcare professionals and to evaluate the knowledge acquired by pregnant women after health education actions.

Methods: Five hundred pregnant women and 141 healthcare professionals from health units in Niterói, state of Rio de Janeiro, answered a questionnaire, received information about toxoplasmosis and had access to an interactive educational model and to folders between 2013 and 2016. After 3 months, 145 pregnant women answered the questionnaire once again.

Results: Of 500 pregnant women, 226 (45.2\%) reported having heard about toxoplasmosis. Among these, $23.5 \%$ had obtained information from friends and $19.0 \%$ from their doctors. About their exposure to risk factors, $6.8 \%$ had had contact with cat feces; $14.0 \%$ had had contact with soil without gloves; $23.4 \%$ had ingested undercooked meat; and $24.0 \%$ had drunk unfiltered water from the public supply system. The questionnaires of 145 pregnant women before and after the educational activities were compared and showed that contact with soil without gloves dropped significantly from $11.0 \%$ to $4.8 \%(\mathrm{p}=0.022)$ while consumption of unfiltered water fell from $26.9 \%$ to $20.0 \%(\mathrm{p}<0.001)$. Washing foods $(62.1 \%)$, washing hands $(62.1 \%)$ and consumption of well-cooked meat $(61.4 \%)$ were the most widely cited preventive measures. Many mistakes were reported among healthcare professionals, and one nursing technician and 13 community healthcare agents $(9.9 \%)$ had not heard about toxoplasmosis.

Conclusions: Lack of knowledge about toxoplasmosis by most of the interviewed pregnant women, in addition to the misconceptions observed among healthcare professionals, leads to the conclusion that little importance has been given so far to primary prevention of toxoplasmosis during the prenatal period. Also, health professionals' inadequate knowledge could be detrimental to secondary prevention, which consists of early detection and treatment of toxoplasmosis during pregnancy. In this study, educational intervention contributed to improving knowledge about the transmission and prevention of toxoplasmosis by pregnant women and, to a lesser extent, to reducing exposure to some risk factors.

KEY WORDS: toxoplasmosis; pregnant women; knowledge; health education; primary prevention.

\section{RESUMO}

Objetivos: Avaliar o conhecimento da toxoplasmose entre gestantes e profissionais de saúde e avaliar o conhecimento adquirido pelas gestantes após ações de educação em saúde.

Métodos: Quinhentas gestantes e 141 profissionais de saúde provenientes de Unidades de Saúde de Niterói-RJ de 2013 a 2016 , foram entrevistados por meio de um questionário, receberam informações sobre a toxoplasmose, tiveram acesso a um modelo educativo interativo e folders. Após três meses, 145 gestantes responderam novamente ao questionário.

Resultados: Das 500 gestantes, $226(45,2 \%)$ relataram que já tinham ouvido falar sobre toxoplasmose. Destas, 23,5\% tiveram informações por amigos e $19,0 \%$ pelo médico. Sobre exposição aos fatores de risco, $6,8 \%$ relataram contato com fezes de gatos; $14,0 \%$ tiveram contato com o solo sem luvas; $23,4 \%$ ingeriam carne mal passada; e 24,0\% bebiam água de abastecimento público sem filtrar. Ao comparar os questionários de 145 gestantes antes e após atividades educativas, o contato com o solo sem uso de luvas teve redução significativa de $11,0 \%$ para $4,8 \%$ $(\mathrm{p}=0,022)$ e o consumo de água sem filtro reduziu de $26,9 \%$ para $20,0 \%(\mathrm{p}=0,001)$. Foram mais citados como medidas preventivas a lavagem dos alimentos $(62,1 \%)$, a lavagem das mãos $(62,1 \%)$ e o consumo de carne bem cozida $(61,4 \%)$. Dentre os profissionais de saúde, muitos erros foram relatados e um técnico de enfermagem e 13 agentes comunitários de saúde $(9,9 \%)$ não conheciam a toxoplasmose.

Conclusões: A falta de conhecimento sobre a toxoplasmose pela maioria das gestantes entrevistadas, além de concepções equivocadas por parte dos profissionais de saúde, levam à conclusão de que vem sendo dada pouca importância para a prevenção primária da toxoplasmose durante o período pré-natal. Adicionalmente, algumas falhas no conhecimento dos profissionais podem prejudicar até mesmo a prevenção secundária, que consiste na detecção e tratamento precoce da toxoplasmose na gestação. Neste estudo, a intervenção educacional contribuiu para aumentar o conhecimento sobre a transmissão e a prevenção da toxoplasmose entre as gestantes e, em menor extensão, para reduzir a exposição a alguns fatores de risco.

DESCRITORES: toxoplasmose; gestantes; conhecimento; educação em saúde; prevenção primária. 
Abbreviations: CAPES, Coordenação de aperfeiçoamento de pessoal de nível superior, Fiocruz, Fundação Oswaldo Cruz; IBGE, Instituto Brasileiro de Geografia e Estatística; IOC, Instituto Oswaldo Cruz; PCSA, Policlínica Comunitária Sérgio Arouca; PMF, Programa Médico de Família; PRLB, Policlínica Regional do Largo da Batalha; PVC, Policloreto de vinila (Polyvinyl chloride); SPSS, statistical package for the social sciences; TCLE, Termo de Consentimento Livre e Esclarecido; T. gondii, Toxoplasma gondii.

\section{INTRODUCTION}

Maternal-fetal transmission of Toxoplasma gondii occurs when tachyzoites present in the maternal circulation reach the placenta and are transmitted to the conceptus [1]. The assumption is that congenital transmission only occurs during primary maternal infection, although there have been reports that it can also happen during the chronic phase of infection [2-4] or in reinfections [5]. The severity of the congenital infection is inversely proportional to the period of gestation when infection occurs, meaning that infections that occur early in pregnancy may be more severe for the fetus. This damage may include fetal death, hydrocephalus, microcephaly, cerebral calcifications, mental retardation, and retinochoroidal lesions. As infection in the last months of gestation is more common, most cases of congenital toxoplasmosis are asymptomatic at birth. Even these cases, however, need treatment [6-9].

To avoid congenital toxoplasmosis and its complications, prevention measures need to be adopted. Primary prevention consists of educational healthcare programs, with the objective of providing pregnant women with guidance on measures to prevent infection [10,11]. Secondary prevention consists of performing serological screening during the prenatal period with the aim of detecting and treating acute $T$. gondii infections, so as to avoid fetal infection and reduce the sequelae of congenital toxoplasmosis $[6,12,13]$. Tertiary prevention is carried out on newborns through laboratory and clinical diagnoses, in order to identify and treat neonates with subclinical congenital toxoplasmosis so as to prevent later complications, particularly ocular complications [14].

The risk of congenital toxoplasmosis is related to the prevalence of the disease in the population and to the number of women of childbearing age who have still not been affected by the disease and are capable of contracting it over the course of a pregnancy [15]. Thus, the importance of primary prevention [16-21], early diagnosis and treatment, and case notification, should be emphasized, so as to prevent or attenuate fetal infection [22]. The supply of educational material with information about the prevention of $T$. gondii infection has been effective in reducing seroconversion rates [23,24]. Furthermore, effective treatment during pregnancy and early childhood can also contribute towards a favorable outcome in children born to mothers with toxoplasmosis acquired during gestation $[25,26]$.

The objectives of the present study were to evaluate the knowledge of healthcare professionals and pregnant women treated in the public healthcare system about toxoplasmosis and its forms of transmission, clinical manifestations, diagnosis, and prevention and to evaluate the knowledge acquired by pregnant women after health education actions.

\section{METHODS}

This study was carried out in the state of Rio de Janeiro in Niterói, which is a medium-sized municipality that covers an area of $133,916 \mathrm{~km}^{2}$. Its population, according to the 2015 census data from the Brazilian Institute of Geography and Statistics (IBGE: Instituto Brasileiro de Geografia e Estatística), was around 496,696 inhabitants, with an urbanization rate of practically $100 \%$. Niterói presents unequal urban growth, with high-class districts of upper and middleclass social strata coexisting side by side with favelas, where houses have precarious construction standards and low-income populations are concentrated. According to data from the Portal Brasil sem Miséria in April 2016, 2,602 families were considered to be living in extreme poverty.

A cross-sectional study was conducted, addressing healthcare professionals and pregnant women in 19 public health facilities: 17 modules out of a total of 29 of the family doctor program (PMF, Programa Médico de Família); Largo da Batalha Regional Polyclinic (PRLB, Policlínica Regional Largo da Batalha); and Sérgio Arouca Community Polyclinic (PCSA, Policlínica Comunitária Sérgio Arouca). Low-risk prenatal care is provided at PMF, PRLB and PCSA. Each unit has a defined coverage area and a certain number of registered families. If any abnormality is detected during pregnancy, the patients can be referred to another polyclinic where high-risk prenatal care is provided, or to the maternity wards of the Azevedo Lima State Hospital and the Antônio Pedro University Hospital affiliated with the Fluminense Federal University, both located in Niterói. 
The project was approved by the Research Ethics Committee of Oswaldo Cruz Foundation (Fiocruz) under the terms of Resolution No. 466/2012 of the Brazilian National Health Council, and all participants signed a free and informed consent form.

During the first stage of the survey, between April 2013 and January 2016, conducted in the 19 surveyed facilities, participants were selected by convenience sampling. All healthcare professionals and pregnant women seen in the facilities during this period were invited to answer a questionnaire about $T$. gondii transmission, clinical manifestations and prevention of toxoplasmosis. Healthcare professionals and pregnant women who refused to participate were not included, nor individuals with dementia and with hearing or cognitive disabilities.

All interviews were carried out in the workplaces of the healthcare professionals and in the places where the pregnant women sought medical care. The risk of interviewing the same person twice was eliminated, since the name of the participants was recorded in the questionnaire and in the consent form. Each healthcare professional answered the questionnaire individually in the presence of the researchers. The pregnant women were also interviewed individually while they waited for prenatal consultations and their anonymity was preserved. The researcher read out the questions without giving any response options and noted down the answers. The questionnaires for pregnant women and health professionals were different: questions about the serological diagnosis of toxoplasmosis were asked only to doctors and nurses and questions about professional conduct were addressed to all health professionals.

The second stage of the study consisted of an intervention program and was conducted in two facilities: PRLB and PCSA. These healthcare units were chosen because they had the greatest number of pregnant women. Educational activities regarding health and toxoplasmosis were implemented among the participants of these two centers. The activities included guidance about protozoan diseases, reading and distribution of informative folders, and access to an interactive educational model that was exhibited at these two centers.

The interactive educational model was constructed based on a study by Bolais et al. [27]. It was presented at the Sciences and Arts module of the Bioscience and Health Teaching Specialization Course of the Oswaldo Cruz Institute in September 2010 and was authorized for use and adaptation for the purposes of the present study. The model can be used in the waiting rooms of prenatal outpatient services with the objective of giving guidance on disease prevention. The proposal consisted of a full-size model of a human figure (a pregnant woman in this case) constructed in polyvinyl chloride (PVC). The images and texts were placed on a revolving disc fixed to the interior of the model. When the disc was rotated, informative text was displayed in the form of bullet points with corresponding illustrations. This material was exhibited in the hall near the consultation offices on the days when there were prenatal care consultations at PRLB and PCSA, and the users were free to explore it. There was no interference from the researchers with regard to how the pregnant women manipulated the model. When the consultations were finished, the material was stored and was exhibited again on the next day of prenatal care.

The third stage of the study was conducted about three months after the previous stage only among pregnant women at PRLB and consisted of reapplying the questionnaire, following the same procedure as in the first stage.

Descriptive statistics were used for data analyses and the results were expressed as frequencies and percentages. The associations were analyzed using the Pearson's chi-square test. The results for the multiple logistic regression were expressed as odds ratio (OR) and $95 \%$ confidence interval $(95 \% \mathrm{CI})$. Comparison between data before and after the educational activity among the pregnant women was done through the Wilcoxon test. The results were considered statistically significant when $\mathrm{p}<0.05$. The data were analyzed using the SPSS Statistics 17 software.

\section{RESULTS}

A total of 141 healthcare professionals participated in the present study. Of these, 23 were doctors, 22 nurses, 36 nursing technicians, and 60 community health agents. Among the interviewees, 127 (90.1\%) reported knowing about toxoplasmosis, while one nursing technician and $13(9.9 \%)$ community health agents reported not knowing about the disease. Of the 141 healthcare professionals, $116(82.3 \%)$ were female and $25(17.7 \%)$ male, with ages ranging between 20 and 64 years. The length of time working in the field of healthcare varied from less than 1 year to more than 10 years. Out of the total number of professionals, $81(57.4 \%)$ reported guiding pregnant women about toxoplasmosis: $41(29.1 \%)$ at the beginning of prenatal care, $23(16.3 \%)$ in all prenatal consultations and $13(9.2 \%)$ only after obtaining the serological test results, $4(2.8 \%)$ in other periods. Twenty-two 
$(15.6 \%)$ professionals reported that pregnant women spontaneously asked questions about toxoplasmosis.

Information obtained through the questionnaire regarding forms of transmission of $T$. gondii, clinical manifestations, and preventive measures that were reported by the healthcare professionals are described in Table 1. The doctors and nurses' responses regarding the diagnosis of toxoplasmosis are described in Table 2.

Table 1. Description of knowledge about Toxoplasma gondii transmission, clinical manifestations and prevention reported by 127 healthcare professionals from the public healthcare system of Niterói, state of Rio de Janeiro, Brazil, $2013-2016$.

\begin{tabular}{|c|c|c|c|c|c|}
\hline Variables & $\begin{array}{l}\text { Physicians } \\
\begin{array}{c}(n=23) \\
n(\%)\end{array}\end{array}$ & $\begin{array}{l}\text { Nurses } \\
\begin{array}{c}(n=22) \\
n(\%)\end{array}\end{array}$ & $\begin{array}{c}\text { Nursing } \\
\text { technicians } \\
(n=35) \\
n(\%)\end{array}$ & $\begin{array}{l}\text { Community } \\
\text { health agents } \\
(n=47) \\
n(\%)\end{array}$ & $\begin{array}{c}\text { Total } \\
(n=127) \\
n(\%)\end{array}$ \\
\hline \multicolumn{6}{|l|}{ Correct information about $T$. gondii transmission } \\
\hline Consumption of raw and/or undercooked meat of mammals and birds & $18(78.2)$ & $9(40.9)$ & $17(48.6)$ & $15(31.9)$ & $59(46.5)$ \\
\hline Consumption of vegetables and fruits without proper hygiene & $9(39.1)$ & $4(18.1)$ & $11(31.4)$ & $7(14.9)$ & $31(24.4)$ \\
\hline Contact and ingestion of oocysts present in cat feces & $23(100.0)$ & $19(86.4)$ & $31(88.6)$ & $42(89.4)$ & $115(90.6)$ \\
\hline Transplacental transmission & $19(82.6)$ & $15(68.2)$ & $17(48.6)$ & $18(38.3)$ & $69(54.4)$ \\
\hline Consumption of raw milk & $7(30.4)$ & $2(9.1)$ & $3(8.6)$ & $2(4.3)$ & $14(11.1)$ \\
\hline \multicolumn{6}{|l|}{ Incorrect information about $T$. gondii transmission } \\
\hline Consumption of raw and/or undercooked meat of fishes & $5(21.7)$ & $2(9.1)$ & $3(8.6)$ & $1(2.1)$ & $11(8.7)$ \\
\hline Contact with pigeon feces & $6(26.1)$ & $6(27.3)$ & $12(34.3)$ & $17(36.2)$ & $41(32.2)$ \\
\hline Contact with dog feces & $10(43.5)$ & $3(13.6)$ & $8(22.8)$ & $14(29.8)$ & $35(27.6)$ \\
\hline \multicolumn{6}{|l|}{ Clinical manifestations } \\
\hline May not cause symptoms & $22(95.6)$ & $11(50.0)$ & $13(37.1)$ & $15(31.9)$ & $61(48.0)$ \\
\hline It looks like flu and may cause headache, fever, malaise, muscle and joint pain & $15(65.2)$ & $6(27.3)$ & $6(17.1)$ & $17(36.2)$ & $44(34.6)$ \\
\hline Hypertrophic lymph nodes in the armpit, groin and neck & $15(65.2)$ & $8(36.4)$ & $11(31.4)$ & $10(21.3)$ & $44(34.6)$ \\
\hline Visual changes and loss of vision & $18(78.2)$ & $12(54.5)$ & $28(80.0)$ & $26(55.3)$ & $84(66.1)$ \\
\hline Fetal malformation & $20(86.9)$ & $12(54.5)$ & $25(71.4)$ & $21(44.7)$ & $78(61.4)$ \\
\hline Abortion & $18(78.2)$ & $8(36.4)$ & $9(25.7)$ & $16(34.0)$ & $51(40.2)$ \\
\hline Do not know & 0 & $1(4.5)$ & 0 & $4(8.5)$ & $5(3.9)$ \\
\hline \multicolumn{6}{|l|}{ Forms of prevention } \\
\hline Washing raw foods with clean water & $15(65.2)$ & $10(45.5)$ & $11(31.4)$ & $15(31.9)$ & $51(40.1)$ \\
\hline Washing hands before and after handling food, soil and cat litter box & $23(100.0)$ & $21(95.5)$ & $23(65.7)$ & $36(76.6)$ & $103(81.1)$ \\
\hline Not ingesting raw or undercooked meat & $18(78.2)$ & $10(45.5)$ & $18(51.4)$ & $15(31.9)$ & $61(48.0)$ \\
\hline Wearing gloves when handling soil or cat litter box & $19(82.6)$ & $16(72.7)$ & $15(42.8)$ & $33(70.2)$ & $83(65.4)$ \\
\hline Feeding cats with cat food or well-cooked meat & $13(56.5)$ & $8(36.4)$ & $7(20.0)$ & $9(19.1)$ & $37(29.1)$ \\
\hline $\begin{array}{l}\text { When a pregnant woman gets infected, she should look for medical assistance } \\
\text { to avoid transmission to her baby }\end{array}$ & $23(100.0)$ & $20(90.9)$ & $26(74.3)$ & $32(68.1)$ & $101(79.5)$ \\
\hline Do not know & 0 & 0 & $2(5.7)$ & 0 & $2(1.6)$ \\
\hline
\end{tabular}

Table 2. Answers about diagnosis of toxoplasmosis reported by doctors and nurses from the public healthcare system of Niterói, state of Rio de Janeiro, Brazil, 2013-2016.

\begin{tabular}{|c|c|c|}
\hline & $\mathbf{N}$ & $\%$ \\
\hline \multicolumn{3}{|l|}{ What does the detection of IgM anti-T. gondii antibodies indicate? } \\
\hline Chronic infection & 9 & 20.0 \\
\hline Recent acute infection, but may persist for more than 1 year* & 30 & 66.7 \\
\hline Do not know & 6 & 13.3 \\
\hline \multicolumn{3}{|c|}{ Can acute infection be indicated and confirmed by the detection of IgM anti-T. gondii antibodies? } \\
\hline High IgG avidity & 14 & 31.1 \\
\hline Low IgG avidity* & 10 & 22.2 \\
\hline The IgG avidity test does not determine infection time & 10 & 22.2 \\
\hline Do not know & 11 & 24.5 \\
\hline \multicolumn{3}{|c|}{ Do pregnant women with negative serology for anti- $T$. gondii antibodies need to repeat the test until the end of pregnancy? } \\
\hline Yes* & 37 & 82.2 \\
\hline No & 4 & 8.9 \\
\hline Only if symptoms appear & 4 & 8.9 \\
\hline Total & 45 & \\
\hline
\end{tabular}

* Correct answer. 
A total of 500 pregnant women were interviewed during the first stage of the study. Of these, $226(45.2 \%)$ reported having heard about toxoplasmosis, while $274(54.8 \%)$ were unaware of this protozoan disease. The number of pregnant women who reported having obtained information about toxoplasmosis from friends was $53(23.5 \%)$; from their doctor, 43 (19.0\%); at school, 34 (15.0\%); from TV, 27 (11.9\%); from nurses, $14(6.2 \%)$; from flyers, $13(5.8 \%)$; from the Internet, $13(5.8 \%)$; and from newspapers, family members, courses and talks in their workplace and/or from previous pregnancies, 29 (12.8\%). Another $51(22.6 \%)$ reported knowing of cases of toxoplasmosis among family members or friends.

The distribution of pregnant women according to age group, education level, gestational age, number of pregnancies, number of prenatal care appointments, history of abortion, and knowledge about toxoplasmosis is shown in Table 3.

Table 3. Distribution of pregnant women treated in the public healthcare services according to age group, educational level, gestational age, number of pregnancies, number of prenatal care appointments, history of abortion, and toxoplasmosis-related knowledge in Niterói, state of Rio de Janeiro, Brazil, 2013-2016.

\begin{tabular}{|c|c|c|c|c|}
\hline Variables & $\begin{array}{l}\text { Know } \\
\text { n (\%) }\end{array}$ & $\begin{array}{c}\text { Do not Know } \\
n(\%)\end{array}$ & $\begin{array}{l}\text { Total } \\
\text { n (\%) }\end{array}$ & $\mathbf{p}^{*}$ \\
\hline Age group (years) & & & & $<0.001$ \\
\hline $13-20$ & $48(28.2)$ & $122(71.8)$ & $170(100.0)$ & \\
\hline $21-30$ & $119(50.6)$ & $116(49.4)$ & $235(100.0)$ & \\
\hline $31-43$ & $59(62.1)$ & $36(37.9)$ & 95 (100.0) & \\
\hline Educational level & & & & $<0.001$ \\
\hline Illiterate & - & $1(100.0)$ & $1(100.0)$ & \\
\hline Incomplete elementary school & $31(23.1)$ & $103(76.9)$ & $134(100.0)$ & \\
\hline Complete elementary school & 17 (39.5) & $26(60.5)$ & $43(100.0)$ & \\
\hline Incomplete high school & $53(37.6)$ & $88(62.4)$ & $141(100.0)$ & \\
\hline Complete high school & $95(66.0)$ & $49(34.0)$ & $144(100.0)$ & \\
\hline Incomplete higher education & $18(81.8)$ & $4(18.2)$ & $22(100.0)$ & \\
\hline Complete higher education & $12(80.0)$ & $3(20.0)$ & $15(100.0)$ & \\
\hline Gestational age & & & & 0.372 \\
\hline First trimester (2-12 weeks) & $48(40.0)$ & $72(60.0)$ & $120(100.0)$ & \\
\hline Second trimester (13- 24 weeks) & $103(45.8)$ & $122(54.2)$ & $225(100.0)$ & \\
\hline Third trimester (25- 41weeks) & $75(48.4)$ & $80(51.6)$ & $155(100.0)$ & \\
\hline Number of pregnancies & & & & 0.014 \\
\hline 1 & $87(38.2)$ & $141(61.8)$ & $228(100.0)$ & \\
\hline 2 & $71(50.0)$ & $71(50.0)$ & $142(100.0)$ & \\
\hline 3 or more & $68(52.3)$ & $62(47.7)$ & $130(100.0)$ & \\
\hline Number of prenatal care appointments & & & & 0.056 \\
\hline 1 & $63(40.6)$ & $92(59.4)$ & $155(100.0)$ & \\
\hline $2-5$ & $114(44.2)$ & $144(55.8)$ & $258(100.0)$ & \\
\hline$>5$ & $49(56.3)$ & $38(43.7)$ & $87(100.0)$ & \\
\hline Abortion & & & & 0.021 \\
\hline Yes & $53(55.8)$ & $42(44.2)$ & 95 (100.0) & \\
\hline No & $173(42.7)$ & $232(57.3)$ & $405(100.0)$ & \\
\hline Total & $226(45.2)$ & $274(54.8)$ & $500(100.0)$ & \\
\hline
\end{tabular}

Know $=$ know about toxoplasmosis. Do not know $=$ do not know about toxoplasmosis.

* Pearson's chi-square test. 
The analysis of exposure to risk factors and knowledge about toxoplasmosis reported in the first stage is described in Table 4.

During the third stage of the study, 145 pregnant women were interviewed. The results for the comparison of knowledge of the modes of transmission, clinical manifestations, and prevention, as well as the reported exposure to risk factors for toxoplasmosis before and after the educational intervention are described in Table 5.

Table 4. Analysis of eating and hygiene habits, and behavioral variables associated with knowledge about toxoplasmosis among pregnant women treated in the public healthcare system. Niterói, state of Rio de Janeiro, Brazil, 2013-2016.

\begin{tabular}{|c|c|c|c|c|c|}
\hline Variables & $\begin{array}{l}\text { Know } \\
\text { n (\%) }\end{array}$ & $\begin{array}{c}\text { Do not know } \\
n(\%)\end{array}$ & $\begin{array}{l}\text { Total } \\
\text { n (\%) }\end{array}$ & $\mathbf{p}^{*}$ & OR $(95 \% \mathrm{Cl})$ \\
\hline \multicolumn{6}{|l|}{ Contact with cat feces } \\
\hline Yes & $17(50.0)$ & $17(50.0)$ & $34(100.0)$ & \multirow[t]{2}{*}{0.560} & \multirow[t]{2}{*}{$1.2(0.6-2.5)$} \\
\hline No & 209 (45.9) & $257(58.1)$ & $466(100.0)$ & & \\
\hline \multicolumn{6}{|l|}{ Contact with soil without gloves } \\
\hline Yes & $40(57.1)$ & $30(42.9)$ & $70(100.0)$ & \multirow[t]{2}{*}{0.030} & \multirow[t]{2}{*}{$1.7(1.1-2.9)$} \\
\hline No & $186(43.3)$ & $244(56.7)$ & $430(100.0)$ & & \\
\hline \multicolumn{6}{|c|}{ Consumption of fruit and vegetable without adequate hygiene } \\
\hline Yes & $26(50.0)$ & $26(50.0)$ & $52(100.0)$ & \multirow[t]{2}{*}{0.463} & \multirow[t]{2}{*}{$1.2(0.6-2.2)$} \\
\hline No & $200(44.6)$ & $248(55.4)$ & $448(100.0)$ & & \\
\hline \multicolumn{6}{|l|}{ Consumption of raw meat } \\
\hline Yes & $17(35.4)$ & $31(64.6)$ & $48(100.0)$ & \multirow[t]{2}{*}{0.152} & \multirow[t]{2}{*}{$0.6(0.3-1.1)$} \\
\hline No & $209(46.2)$ & $243(53.8)$ & $452(100.0)$ & & \\
\hline \multicolumn{6}{|l|}{ Consumption of undercooked meat } \\
\hline Yes & $46(39.3)$ & $71(60.7)$ & $117(100.0)$ & \multirow[t]{2}{*}{0.144} & \multirow[t]{2}{*}{$0.7(0.5-1.1)$} \\
\hline No & $180(47.0)$ & $203(53.0)$ & $383(100.0)$ & & \\
\hline \multicolumn{6}{|c|}{ Consumption of raw or undercooked embedded meat } \\
\hline Yes & $43(48.3)$ & $46(51.7)$ & $89(100.0)$ & \multirow[t]{2}{*}{0.515} & \multirow[t]{2}{*}{$1.1(0.7-1.8)$} \\
\hline No & $183(44.5)$ & $228(55.5)$ & $411(100.0)$ & & \\
\hline \multicolumn{6}{|l|}{ Consumption of raw milk } \\
\hline Yes & $25(47.2)$ & $28(52.8)$ & $53(100.0)$ & \multirow[t]{2}{*}{0.761} & \multirow[t]{2}{*}{$1.1(0.6-1.9)$} \\
\hline No & $201(45.0)$ & $246(55.0)$ & 447 (100.0) & & \\
\hline \multicolumn{6}{|l|}{ Drinking water } \\
\hline Public supply, filtered & $148(48.7)$ & $156(51.3)$ & $304(100.0)$ & \multirow[t]{5}{*}{$<0.001$} & - \\
\hline Public supply, unfiltered & $34(28.3)$ & $86(71.7)$ & $120(100.0)$ & & \\
\hline Well water, filtered & $3(60.0)$ & $2(40.0)$ & $5(100.0)$ & & \\
\hline Well water, unfiltered & $1(100.0)$ & $0(0.0)$ & $1(100.0)$ & & \\
\hline Bottled mineral water & $40(57.1)$ & 30 (42.9) & $70(100.0)$ & & \\
\hline \multicolumn{6}{|l|}{ Presence of rats at home } \\
\hline Yes & $82(41.4)$ & $116(58.6)$ & $198(100.0)$ & \multirow[t]{2}{*}{0.168} & \multirow[t]{2}{*}{$0.8(0.5-1.1)$} \\
\hline No & $144(47.7)$ & $158(52.3)$ & $302(100.0)$ & & \\
\hline Total & $226(45.2)$ & $274(54.8)$ & $500(100.0)$ & & \\
\hline
\end{tabular}

$\mathrm{OR}$, odds ratio; $\mathrm{Cl}$, confidence interval.

Know $=$ know about the risk factor for toxoplasmosis; Do not know $=$ do not know about the risk factor for toxoplasmosis.

* Pearson's chi-square test. 
Table 5. Evaluation of knowledge about transmission, symptoms and prevention of toxoplasmosis and analysis of risk factors for Toxoplasma gondii infection among 145 pregnant women treated in the public healthcare system before and after primary prevention activities. Niterói, state of Rio de Janeiro, Brazil, 2013-2016.

\begin{tabular}{|c|c|c|c|}
\hline Variables & $\begin{array}{c}\text { Before } \\
\text { n (\%) }\end{array}$ & $\begin{array}{l}\text { After } \\
\text { n (\%) }\end{array}$ & $\mathbf{p}^{*}$ \\
\hline \multicolumn{4}{|l|}{ Modes of transmission } \\
\hline Consumption of raw and undercooked meat & $4(2.8)$ & $81(55.9)$ & $<0.001$ \\
\hline Consumption of fruit and vegetable without adequate hygiene & $7(4.8)$ & $82(56.6)$ & $<0.001$ \\
\hline Contact with cat feces & $30(20.7)$ & $115(79.3)$ & $<0.001$ \\
\hline Contact with pigeon feces & $2(1.4)$ & $2(1.4)$ & 1.000 \\
\hline Contact with dog feces & $8(5.5)$ & $4(2.8)$ & 0.344 \\
\hline Do not know & $104(71.7)$ & $23(15.8)$ & $<0.001$ \\
\hline \multicolumn{4}{|l|}{ Symptoms } \\
\hline Causes no symptoms & $0(0)$ & $0(0)$ & 1.000 \\
\hline Fever, headache and muscle pain & $0(0)$ & $9(6.2)$ & 0.004 \\
\hline Lumps in the armpits, groin, and neck & $2(1.4)$ & $1(0.7)$ & 1.000 \\
\hline Visual impairment & $7(4.8)$ & $15(10.3)$ & 0.077 \\
\hline Fetal malformations & $5(3.4)$ & $38(26.2)$ & $<0.001$ \\
\hline Abortion & $1(0.7)$ & $10(6.9)$ & 0.004 \\
\hline Do not know & $132(91.0)$ & $91(62.7)$ & $<0.001$ \\
\hline \multicolumn{4}{|l|}{ Forms of prevention } \\
\hline Washing raw foods with clean water & $7(4.8)$ & $90(62.1)$ & $<0.001$ \\
\hline Washing hands before and after handling food, soil and cat litter box & $5(3.4)$ & $90(62.1)$ & $<0.001$ \\
\hline Not ingesting raw or undercooked meat & $6(4.1)$ & $89(61.4)$ & $<0.001$ \\
\hline Wearing gloves when handling soil or cat litter box & $3(2.1)$ & $68(46.9)$ & $<0.001$ \\
\hline Feeding cats with cat food or well-cooked meat & $2(1.4)$ & $39(26.9)$ & $<0.001$ \\
\hline When a pregnant woman gets infected, she should look for medical assistance to avoid transmission to her baby & $2(1.4)$ & $61(42.1)$ & $<0.001$ \\
\hline Do not know & $121(83.4)$ & $29(20.0)$ & $<0.001$ \\
\hline Knew that toxoplasmosis can be transmitted from mother to baby during pregnancy & $41(28.3)$ & $138(95.2)$ & $<0.001$ \\
\hline Knew it was important to have a blood test for diagnosis of toxoplasmosis & $23(15.9)$ & $131(90.3)$ & $<0.001$ \\
\hline Knew that toxoplasmosis is treatable & $24(16.6)$ & $117(80.7)$ & $<0.001$ \\
\hline \multicolumn{4}{|l|}{ Exposure to risk factors } \\
\hline Contact with cat feces & $4(2.8)$ & $3(2.1)$ & 1.000 \\
\hline Contact with soil without gloves & $16(11.0)$ & $7(4.8)$ & 0.022 \\
\hline Consumption of fruit and vegetables without adequate hygiene & $13(9.0)$ & $9(6.2)$ & 0.481 \\
\hline Consumption of raw meat & $15(10.3)$ & $10(6.9)$ & 0.332 \\
\hline Consumption of undercooked meat & $30(20.7)$ & $26(17.9)$ & 0.572 \\
\hline Consumption of embedded meat & $28(19.3)$ & $21(14.5)$ & 0.248 \\
\hline Consumption of raw milk & $18(12.4)$ & $12(8.3)$ & 0.210 \\
\hline Unfiltered water & $39(26.9)$ & $29(20.0)$ & 0.004 \\
\hline Presence of rats at home & $57(39.3)$ & $58(40.0)$ & 1.000 \\
\hline
\end{tabular}

* Wilcoxon's test.

\section{DISCUSSION}

In the present study, more than $90 \%$ of the healthcare professionals interviewed had in mind a strong relation between transmission of $T$. gondii and contact with and ingestion of oocytes present in cat feces. However, other modes of transmission, such as ingestion of raw or undercooked meat, and 
consumption of unwashed vegetables and fruit, were mentioned less frequently. Ingestion of oocytes present in the environment and consumption of meat with bradyzoite cysts are the two most important modes of transmission of T. gondii [28].

Only half of the professionals mentioned transplacental transmission. Another study conducted in Cascavel, state of Paraná, showed that more than $90 \%$ of the surveyed doctors and nurses knew that toxoplasmosis could be acquired during the first, second, or third trimester of gestation, and that about half of them knew the risk of congenital transmission increases with gestational trimester [20]. This difference can be probably explained by the fact that there is a greater concern for the continued training of professionals in Paraná. Since 2009, a health surveillance program for gestational and congenital toxoplasmosis, which has health education as one of its pillars, has been developed and implemented in some municipalities. This program revealed significant improvement in the care of pregnant women and children with suspected or confirmed toxoplasmosis $[29,30]$. However, toxoplasmosis prevention methods are not homogeneous among public health services and, in Niterói, there were no programs for promoting the update of professionals about congenital toxoplasmosis prevention, which may explain the difference in the results.

Some misconceptions about the modes of transmission were observed among healthcare professionals. Some of them wrongly attributed toxoplasmosis transmission to the consumption of raw and undercooked fish and to contact with pigeon feces and dog feces. However, even though dogs do not eliminate $T$. gondii oocytes in their feces, they may play an important role in the transmission of this parasite. These animals can transmit oocytes mechanically and, in some parts of the world, dog meat is used for human consumption [31].

In a study carried out among doctors and nurses in Juiz de Fora, state of Minas Gerais, almost all of the healthcare professionals recognized cats as animals that eliminate oocytes in their feces, but only half also reported that dogs eliminate oocytes [16]. Another study carried out among healthcare professionals in Maringá, state of Paraná, demonstrated that most professionals did not know which evolutionary forms of $T$. gondii could infect human beings [17].

The most widely mentioned clinical manifestations in the present study were visual alterations and problems with the fetus. Almost half of the surveyed healthcare professionals recognized that the infection can be asymptomatic, while in a study conducted in the Juiz de Fora, state of Minas Gerais, 74\% of the professionals knew that toxoplasmosis could occur without symptoms [16].

Regarding knowledge of preventive measures, washing hands before handling food and after handling soil or litter boxes, and recognizing the need for medical assistance and treatment when a pregnant woman becomes infected were mentioned by all participants. Other possible prevention measures were mentioned less often, which was expected considering the low level of knowledge among healthcare professionals about modes of transmission of $T$. gondii. These data indicate a possible flaw in the academic training of these professionals, who were shown in the present study to be lacking in knowledge about $T$. gondii infection. This is a cause for concern, since these professionals must be able to give information to pregnant women. Healthcare professionals need to know the habits of their patients to be able to guide them on preventive measures.

Another alarming factor observed in the present study is related to the knowledge of the diagnosis of toxoplasmosis among both doctors and nurses. Many of the professionals did not know how to interpret serological test results, which could lead to errors in conduct and could compromise the health of mother and fetus. Only about one fifth of the professionals knew that a low IgG avidity could aid in the confirmation of the acute phase of the infection and $66.7 \% \mathrm{knew}$ that anti- $T$. gondii $\operatorname{IgM}$ antibodies indicate a recent infection. In another study conducted in the state of Paraná, physicians and nurses also had difficulty interpreting and recognizing the importance of the $\operatorname{IgG}$ avidity test [20]. Studies conducted in other Brazilian states with healthcare professionals who work with prenatal care have already signaled the need to train them in this subject $[16,17,20]$. The role of healthcare professionals, particularly those working in prenatal outpatient services, is the most efficient for educational purposes. However, lack of time and/or interest in healthcare promotion activities and low quality of educational materials have a negative effect on the educational programs of healthcare units [23].

A previous study was conducted with 405 pregnant women about the factors associated with knowledge about toxoplasmosis, and the proportion of pregnant women with toxoplasmosis-related knowledge increased with age, educational level and the number of pregnancies. History of abortion was also associated with toxoplasmosis-related knowledge [32]. The same result was observed for 500 pregnant women. 
When comparing the knowledge of pregnant women with exposure to risk factors reported in the first stage, we observed that the percentage of pregnant women who consumed raw or undercooked meat, raw or undercooked embedded meat, unpasteurized milk, and unfiltered water from a public supply was higher among women who reported knowing nothing about toxoplasmosis, but there was no statistically significant association, except for drinking unfiltered water. Surprisingly, contact with the soil without gloves was significantly associated with pregnant women who reported knowledge about toxoplasmosis. This can be explained by the fact that the question that was asked was whether they knew about toxoplasmosis and not whether they knew that the parasite can be transmitted by contact with the soil without gloves.

After the educational activities, knowledge about the modes of transmission of $T$. gondii and preventive measures showed a statistically significant improvement. The surveyed pregnant women began to identify serious problems related to their babies and abortion as important clinical manifestations of toxoplasmosis. There was some improvement in the knowledge about vertical transmission of $T$. gondii, about the importance of serological tests for the diagnosis of toxoplasmosis, and about the need to treat toxoplasmosis. Nevertheless, although there was some significant improvement in knowledge, after the educational intervention many pregnant women still had doubts or misconceptions about infection.

Regarding exposure to risk factors after the educational program, contact with soil without wearing gloves and consumption of unfiltered water had a statistically significant decrease. However, most pregnant women did not demonstrate a change in their habits even in relation to those factors about which they reported having acquired knowledge. These findings demonstrate that continuity in healthcare education and guidance are necessary for changes in habits. In the present study, the educational intervention was done only once and showed a positive effect on knowledge. If this intervention had been repeated during pregnancy, more cases of $T$. gondii transmission to the conceptus could probably have been prevented. The effectiveness of a program that involves changes in lifestyle is associated with the widespread and repeated information about risk factors as well as with the participation of all health professionals and patients.

Studies of pregnant women in Europe have demonstrated the positive effect of knowledge about exposure to risk factors and primary prevention of toxoplasmosis. However, the authors of those studies identified that the effect of educational materials depends on the intellectual level of the population and on individual motivation to learn more about how to adopt a healthier lifestyle, especially during pregnancy $[23,24]$.

A classic study on primary prevention of congenital toxoplasmosis revealed a $63 \%$ decrease in seroconversion rate during pregnancy after application of hygiene measures following an intensive educational program [33]. Unfortunately, in some (or probably most) Brazilian municipalities, this practice is not given proper consideration, such as in Maringá, state of Paraná, where only $16.2 \%$ of the pregnant women received guidance on prevention of toxoplasmosis [17], and in Juiz de Fora, state of Minas Gerais, where a study among doctors and nurses revealed several errors regarding toxoplasmosis prevention and diagnosis [16].

Further studies are still necessary to confirm the efficiency of this type of intervention, as highlighted in a review article on education regarding congenital toxoplasmosis during the prenatal period, which included two cluster randomized controlled trials conducted in France and Canada, totaling 5,455 pregnant women. The authors of that review concluded that despite evidence from observational studies, the efficiency of primary prevention of toxoplasmosis has not yet been thoroughly evaluated. Even so, educational intervention aimed at primary prevention of toxoplasmosis is desirable, taking into account the absence of risks and its potential benefits [34].

Lack of knowledge about toxoplasmosis by most of the interviewed pregnant women, along with the misconceptions observed among healthcare professionals, leads to the conclusion that little importance has been given so far to primary prevention of toxoplasmosis during the prenatal period. In addition, inadequate knowledge by health professionals could even be detrimental to secondary prevention, i.e., the early detection and treatment of toxoplasmosis during pregnancy. In this study, the educational intervention contributed to improving knowledge about the transmission and prevention of toxoplasmosis by pregnant women and, to a lesser extent, to reducing exposure to some risk factors.

Considering the number of women who are currently susceptible to $T$. gondii infection over the course of pregnancy and who could vertically transmit the parasite to their conceptus, primary prevention is a desirable public healthcare measure that should be implemented in this population. Moreover, it is important that healthcare professionals obtain proper qualification in toxoplasmosis, with special emphasis 
on the correct interpretation of serological tests, modes of transmission of $T$. gondii, and preventive measures, so as to improve the quality of prenatal care.

\section{NOTES}

\section{Acknowledgments}

The authors are deeply indebted to the Graduate Program in Tropical Medicine of IOC-Fiocruz and to the Continuing Education and Research Center of the Municipal Health Foundation (Núcleo de Educação Permanente e Pesquisa da Fundação Municipal de Saúde) of Niterói.

\section{Financial support}

Coordination Office for Improvement of Higher-Education Personnel (Coordenação de aperfeiçoamento de pessoal de nível superior, CAPES), "Brazil without Extreme Poverty" Program (Programa Brasil sem Miséria) and Laboratory of Toxoplasmosis and Other Protozoan Diseases of IOC-Fiocruz.

\section{Conflicts of interest disclosure}

The authors declare no competing interests relevant to the content of this study. They claim to have had full access to all available data and they take full responsibility for the integrity of the results described herein.

\section{REFERENCES}

1. Frenkel JK. Toxoplasmose. In: Veronesi R, Focaccia R. Tratado de infectologia. 2. ed. São Paulo: Atheneu; 2004. p. $1310-25$.

2. Remington JS, McLeod R, Wilson CB, Desmonts G. Toxoplasmosis. In: Remington JS, Klein JO, Wilson CB, Baker CJ. Infectious diseases of the fetus and newborn infant. 7th ed. Philadelphia: Elsevier; 2011. p. 918-1041. https://doi. org/10.1016/B978-1-4160-6400-8.00031-6

3. Brydak-Godowaska J, Borkowski PK, Rabczenko D, Moneta-Wielgoś J, Kecik D. Do pregnancy, postpartum period and lactation predispose to recurrent toxoplasmic retinochoroiditis? Med Sci Monit. 2015;21:582-4. https://doi.org/10.12659/ MSM.892220

4. Garcia AGP. Congenital toxoplasmosis in two successive sibs. Arch Dis Child. 1968;43(232):705-10. https://doi. org/10.1136/adc.43.232.705

5. Gavinet MF, Robert F, Firtion G, Delouvrier E, Hennequin C, Maurin JR, Tourte-Schaefer C, Dupouy-Camet J. Congenital toxoplasmosis due to maternal reinfection during pregnancy. J Clin Microbiol. 1997;35(5):1276-7.

6. Foulon W, Naessens A, Ho-Yen D. Prevention of congenital toxoplasmosis. J Perinat Med. 2000;28(5):337-45. https:// doi.org/10.1515/JPM.2000.043

7. Montoya JG, Liesenfeld O. Toxoplasmosis. Lancet. 2004;363(9425):1965-76. https://doi.org/10.1016/S01406736(04)16412-X

8. Souza CZ, Marchioro AA, Rafael K, Araújo SM, Falavigna-Guilherme AL. Aborto espontâneo e toxoplasmose ocular em um casal infectado com Toxoplasma gondii. Sci Med. 2015;25(3):ID21119. https://doi.org/10.15448/19806108.2015.3.21119

9. Aleixo AL, Curi AL, Benchimol EI, Amendoeira MR. Toxoplasmic retinochoroiditis: clinical characteristics and visual outcome in a prospective study. PLoS Negl Trop Dis. 2016;10(5):e0004685. https://doi.org/10.1371/journal.pntd.0004685

10. Ambroise-Thomas P. Toxoplasmose congénitale: les différentes stratégies préventives. Arch Pediatr. 2003;10 Suppl 1:12-4.

11. Foulon W. Congenital toxoplasmosis: is screening desirable? Scand J Infect Dis Suppl. 1992;84:11-7.

12. Lago EG, Carvalho RL, Jungblut R, Silva VB, Fiori RM. Screening for Toxoplasma gondii antibodies in 2,513 consecutive parturient women and evaluation of newborn infants at risk for congenital toxoplasmosis. Sci Med. 2009;19(1):27-34.

13. Spalding SM, Amendoeira MRR, Ribeiro LC, Silveira C, Garcia AP, Camillo-Coura L. Estudo prospectivo de gestantes e seus bebês com risco de transmissão de toxoplasmose congênita em município do Rio Grande do Sul. Rev Soc Bras Med Trop. 2003;36(4):483-91. https://doi.org/10.1590/S0037-86822003000400009

14. Paul M, Petersen E, Szczapa J. Prevalence of congenital Toxoplasma gondii infection among newborns from the Pozna region of Poland: validation of a new combined enzyme immunoassay for Toxoplasma gondii-specific immunoglobulin A and immunoglobulin M antibodies. J Clin Microbiol. 2001;39(5):1912-6. https://doi.org/10.1128/JCM.39.5.1912-1916.2001

15. Leão PRD, Meirelles Filho J, Medeiros SF. Toxoplasmosis: seroprevalence in postpartum women attended by SUS (Brazilian Public Health System). Rev Bras Ginecol Obstet. 2004;26(8):627-32. https://doi.org/10.1590/S010072032004000800006

16. da Silva LB, de Oliveira RV, da Silva MP, Bueno WF, Amendoeira MR, de Souza Neves E. Knowledge of toxoplasmosis among doctors and nurses who provide prenatal care in an endemic region. Infect Dis Obstet Gynecol. 2011;2011:750484. https://doi.org/10.1155/2011/750484

17. Branco BHM, Araujo SM, Falavigna-Guilherme AL. Prevenção primária da toxoplasmose: conhecimento e atitudes de profissionais de saúde e gestantes do serviço público de Maringá, estado do Paraná. Sci Med. 2012;22(4):185-90. 
18. Moura FL, Amendoeira MRR, Bastos OMP, Mattos DPBG, Fonseca ABM, Nicolau JL, Neves LB, Millar PR. Prevalence and risk factors for Toxoplasma gondii infection among pregnant and postpartum women attended at public healthcare facilities in the City of Niterói, State of Rio de Janeiro, Brazil. Rev Soc Bras Med Trop. 2013;46(2):200-7. https://doi. org/10.1590/0037-8682-1613-2013

19. Millar PR, Moura FL, Bastos OMP, Mattos DPBG, Fonseca ABM, Sudré AP, Leles D, Amendoeira MRR. Toxoplasmosisrelated knowledge among pregnant and postpartum women attended in public health units in Niterói, Rio de Janeiro, Brazil. Rev Inst Med Trop. 2014;56(5):433-8. https://doi.org/10.1590/S0036-46652014000500011

20. Contiero-Toninato AP, Cavalli HO, Marchioro AA, Ferreira EC, Caniatti MCCL, Breganó RM, Navarro I, FalavignaGuilherme AL. Toxoplasmosis: an examination of knowledge among health professionals and pregnant women in a municipality of the State of Paraná. Rev Soc Bras Med Trop. 2014;47(2):198-203. https://doi.org/10.1590/0037-86820016-2014

21. Rodrigues JB, Nascimento LL, Vieira PS, Rocha RMM, Freitas DRJ, Evangelista LSM. Conhecimento de gestantes sobre toxoplasmose no município de Teresina, Piauí. Rev Prev Infec e Saúde. 2015;1(2):41-6.

22. Capobiango JD, Breganó RM, Mori FMRL, Navarro IT, Campos JSA, Tatakihara LT, Talizin TB, Santos M, Pereira TRG, Narciso SG, Reiche EMV. Toxoplasmose adquirida na gestação e toxoplasmose congênita: uma abordagem prática na notificação da doença. Epidemiol Serv Saúde. 2016;25(1):187-94. https://doi.org/10.5123/s1679-49742016000100020

23. Pawlowski ZS, Gromadecka-Sutkiewicz M, Skommer J, Paul M, Rokossowski H, Suchocka E, Schantz PM. Impact of health education on knowledge and prevention behavior for congenital toxoplasmosis: the experience in Poznań, Poland. Health Educ Res. 2001;16(4):493-502. https://doi.org/10.1093/her/16.4.493

24. Gollub E, Leroy V, Gilbert R, Chêne G, Wallon M, European Toxoprevention Study Group (EUROTOXO). Effectiveness of health education on Toxoplasma-related knowledge, behaviour, and risk of seroconversion in pregnancy. Eur J Obstet Gynecol Reprod Biol. 2008;136(2):137-45. https://doi.org/10.1016/j.ejogrb.2007.09.010

25. Galanakis E, Manoura A, Antoniou M, Sifakis S, Korakaki E, Hatzidaki E, Lambraki D, Tselentis Y, Giannakopoulou C. Outcome of toxoplasmosis acquired during pregnancy following treatment in both pregnancy and early infancy. Fetal Diagn Ther. 2007;22(6):444-8. https://doi.org/10.1159/000106352

26. Amendoeira MRR, Camilo-Coura LF. Uma breve revisão sobre toxoplasmose na gestação. Sci Med. 2010;20(1):113-9.

27. Bolais P, Moraes R, Andrade W. Toxoplasmose e sua prevenção na gestação: proposta de modelo educativo interativo. Rio de Janeiro: Instituto Oswaldo Cruz; 2010. Trabalho apresentado para a disciplina Ciência e Arte do Curso de Especialização em Ensino de Biociências e Saúde.

28. Dubey JP, Lago EG, Gennari SM, Su C, Jones JL. Toxoplasmosis in humans and animals in Brazil: high prevalence, high burden of disease, and epidemiology. Parasitology. 2012;139(11):1375-424. https://doi.org/10.1017/S0031182012000765

29. Mitsuka-Breganó R, Lopes-Mori FMR, Navarro IT. Toxoplasmose adquirida na gestação e congênita: vigilância em saúde, diagnóstico, tratamento e condutas. Londrina: EDUEL; 2010. https://doi.org/10.7476/9788572166768

30. Lopes-Mori FMR, Mitsuka-Breganó R, Capobiango JD, Inoue IT, Reiche EMV, Morimoto HK, Casella AMB, Bittencourt LHFB, Freire RL, Navarro IT. Programas de controle da toxoplasmose congênita. Rev Assoc Med Bras. 2011;57(5): 594-9. https://doi.org/10.1590/S0104-42302011000500021

31. Dubey JP, Huong LT, Sundar N, Su C. Genetic characterization of Toxoplasma gondii isolates in dogs from Vietnam suggests their South American origin. Vet Parasitol. 2007;146(3-4):347-51. https://doi.org/10.1016/j.vetpar.2007.03.008

32. Moura FL, Goulart PRM, Moura APP, Souza TS, Fonseca ABM, Amendoeira MRR. Fatores associados ao conhecimento sobre a toxoplasmose entre gestantes atendidas na rede pública de saúde do município de Niterói, Rio de Janeiro, 2013 2015. Epidemiol Serv Saude. 2016;25(3):655-661. https://doi.org/10.5123/S1679-49742016000300022

33. Foulon W, Naessens A, Derde MP. Evaluation of the possibilities for preventing congenital toxoplasmosis. Am J Perinatol. 1994;11(1):57-62. https://doi.org/10.1055/s-2007-994537

34. Di Mario S, Basevi V, Gagliotti C, Spettoli D, Gori G, D'Amico R, Magrini N. Prenatal education for congenital toxoplasmosis. Cochrane Database Syst Rev. 2015;(10):CD006171. https://doi.org/10.1002/14651858.cd006171.pub4 C 